logos_i_ethos_2013_1_(34), s. 171-189

Roman Rożdżeński

\title{
Pytanie o istotę koniecznego związku, o jakim mówi treść Kartezjuszowej zasady: myślę, więc jestem
}

U początku czasów nowożytnych Kartezjusz (właściwie: René Descartes, 15961650) wystąpił z rewolucyjnym programem zbudowania nowej filozofii, jako wiedzy bezwzględnie pewnej. To zaś, że $\mathrm{z}$ wielką pasją zajął się tą sprawą, było w znacznym stopniu uwarunkowane intelektualną atmosferą czasów, w jakich wypadło mu żyć. W okresie Renesansu dokonał się bowiem we Francji powrót sceptycyzmu, a stało się to w znacznej mierze pod wpływem poglądów głoszonych przez słynnego erudytę

ks. Roman Rożdżeński - profesor, doktor habilitowany filozofii, kierownik Katedry Filozofii Poznania na Wydziale Filozoficznym Uniwersytetu Papieskiego Jana Pawła II w Krakowie. W swoich publikacjach książkowych oraz artykułach zajmuje się przede wszystkim filozofią Husserla, Kanta, Heideggera, Arystotelesa, Ockhama, Nietzschego, Kartezjusza, Lockea, Leibniza, Berkeleya, Hume’a, jak również problematyką sceptycyzmu oraz nihilizmu. i myśliciela, którym był Michel Montaigne (1533-1592). On to mianowicie w swoich rozważaniach ,wskrzesił starożytne dowody za sceptycyzmem, relatywizm poznania zmysłowego, niemożność wzniesienia się intelektu ponad relatywizm do pewnego osiągnięcia absolutnej prawdy". Podkreślając zaś w wieloraki sposób niepewność wszelkich naszych poznawczych usiłowań, Montaigne ciągle powracał tam do pytania: cóż zatem wiem w sposób naprawdę niewątpliwy?2

Ta wyraźna obecność tendencji sceptycznych w intelektualnej atmosferze Francji w wiekach XVI i XVII sprawiła, że przezwyciężenie sceptycyzmu stało się tam „w XVII wieku koniecznym wstępem do filozofii, która nie chciała uchodzić za dogmatyczną. Descartes zdawał 
sobie z tego jasno sprawę"3. Nie da się jednak dokładnie stwierdzić, w jakim zakresie Kartezjusz zapoznał się z argumentami sceptyków. Trudno też powiedzieć, w jakim stopniu ich znajomość miała wpływ na - powzięty później przez niego - zamysł poszukiwania niewzruszonego fundamentu, na którym można by zbudować system nowej filozofii, jako wiedzy bezwzględnie pewnej. Albowiem, choć nie ulega wątpliwości, że na jego przemyślenia miała wpływ argumentacja sceptyków, to przecież w jego własnych pismach nie znajdujemy żadnych wyraźnych wzmianek na ten temat.

Wygląda zarazem na to, że zamysł dokonania radykalnej reformy filozofii miał u Kartezjusza przede wszystkim osobiste uwarunkowanie, gdyż po latach studiów, jakie poświęcił na zdobywanie gruntownej wiedzy, przeżył okres głębokiego zwątpienia w jej wartość. Wspominał o tym później w swojej Rozprawie o metodzie: „Od [...] dzieciństwa byłem chowany w naukach humanistycznych, a ponieważ przekonywano mnie, iż przy ich pomocy można zdobyć jasną i pewną wiedzę o wszystkim, co jest w życiu przydatne, niezmiernie pragnąłem przyswoić je sobie. Z chwilą jednak, gdy ukończyłem cały ten kurs nauk, którego opanowanie wprowadza zazwyczaj do grona uczonych, całkowicie zmieniłem zdanie. Poczułem się bowiem uwikłany w takie mnóstwo wątpliwości i błędów, że zdawało mi się, iż jedyną korzyścią, którą odniosłem z mych usiłowań kształcenia się, było coraz pełniejsze wykrywanie własnej niewiedzy"4.

Wydaje się więc, że ten okres jego intelektualnego kryzysu miał swoje źródło nie tyle w zapoznaniu się przezeń z argumentami sceptyków, ile raczej w tym, że on sam ostro uprzytomnił sobie wówczas fakt permanentnej sprzeczności poglądów, głoszonych dotychczas przez wielkich filozofów, których koncepcje poznał podczas swoich studiów. Dał temu później wyraz w słowach: „O filozofii nie powiem nic ponadto, że widząc ją uprawianą przez najdoskonalsze umysły w ciągu wielu wieków oraz stwierdziwszy, że nie zawiera ona przecież ani jednej tezy niespornej,

I. Dąmbska, Sceptycyzm francuski XVI i XVII wieku, Toruń 1958, s. 77.

4 R. Descartes, Rozprawa o metodzie, tłum. W. Wojciechowska, Warszawa 1988, s. 6n. 
a co za tym idzie, niewątpliwej. [...] poza tym zważywszy, jak wiele może istnieć różnych poglądów dotyczących tego samego przedmiotu, bronionego przez mężów uczonych, gdy tymczasem tylko jeden pogląd może być prawdziwy, uważałem niemal za fałszywe wszystko to, co było tylko prawdopodobne"s. Rozmyślając nad tymi ustawicznymi sporami, jakie dotychczas miały miejsce na terenie filozofii, Kartezjusz doszedł do przeświadczenia, iż rzetelne przemyślenie tych rozmaitych poglądów, jakie w ciągu wieków były głoszone przez wielkich myślicieli i wyłuskanie z nich tego, co wydaje się posiadać trwałą wartość, jest zadaniem niewykonalnym. Dlatego uważał, że wszystkie dotychczasowe doktryny filozoficzne należy po prostu zignorować i podjąć na własną rękę próbę radykalnego przezwyciężenia tej sytuacji intelektualnego zamętu. To swoje przeświadczenie ujął on w słowach: „Nie chcę [...] badać, co inni wiedzieli lub czego nie wiedzieli; wystarczy zauważyć, że gdyby nawet cała wiedza, jakiej można pragnąć, była zawarta w książkach, przecież to, co one mają dobrego, jest pomieszane $\mathrm{z}$ tak wieloma rzeczami nieużytecznymi i rozsiane bezładnie w mnóstwie tak grubych tomów, że trzeba by więcej czasu na ich przeczytanie, aniżeli wystarcza na to nasze życie, i więcej talentu, by z nich wybrać rzeczy pożyteczne, niż by je samodzielnie wynaleźć". W Wszystko to prowadziło go do przeświadczenia, że należy bezzwłocznie wkroczyć na drogę własnego poszukiwania czegoś takiego, co mogłoby okazać się bezspornie pewne.

\section{Kartezjuszowe poszukiwanie czegoś, co byłoby bezwzględnie pewne}

O tym swoim zamyśle, ażeby podjąć samodzielnie trud wytrwałego dążenia do odkrycia czegoś bezwzględnie pewnego, co musiałoby zostać uznane przez wszystkich, wspominał Kartezjusz w swej słynnej Rozprawie o metodzie. Stwierdził tam najpierw mianowicie: „usiłowałem

Tamże, s. 10n.

R. Descartes, Reguly kierowania umysłem. Poszukiwanie prawdy poprzez światło naturalne, tłum. L. Chmaj, Kęty 2002, s. 82. 
rozważyć w każdym przedmiocie to szczególnie, co może czynić go podejrzanym i dać nam sposobność do pomyłek, więc przez cały ten czas wykorzeniałem z mego umysłu wszelkie błędy, które się tam mogły wkraść poprzednio. Nie znaczy to - podkreślał - abym usiłował naśladować sceptyków, którzy wątpią dla samego wątpienia i przybierają pozór ciągłego niezdecydowania, a przeciwnie, cały mój plan zmierzał jedynie do zdobycia pewności i do odrzucenia ruchomej ziemi i piasku, aby wynaleźć skałę lub glinę"7 . Dodawał następnie, że w trakcie tego rodzaju dociekań uprzytomnił sobie pewnego dnia, iż poszukując czegoś takiego, co byłoby bezwzględnie pewne, należy najpierw w tym celu - niejako prowizorycznie - zwątpić we wszystko, co mogłoby nasuwać najmniejszą choćby wątpliwość. Odpowiednio do tego, uznał on za całkowicie niewiarygodne to wszystko, co:

(A) bądź to pochodzi ze świadectwa naszych zmysłów;

(B) bądź jest wynikiem naszych rozumowań, opartych na racjach, którym - jak mniemamy - zawsze jest posłuszny nasz umysł;

(C) bądź też jest treścią naszego myślenia (tj. naszego świadomego przeżywania).

Uzasadniając to swoje przeświadczenie, wskazywał, że gdy idzie o pierwszą sprawę, to skoro „nasze zmysły niekiedy nas zwodzą, zamierzałem przyjąć, że nie istnieje ani jedna rzecz, która by była taką, jaką wydaje się nam za ich sprawą"8. Albowiem, skoro przekonałem się o tym, że moje zmysły niekiedy mnie zwodzą, to „roztropność nakazuje nie ufać nigdy w zupełności tym, którzy nas chociaż raz zwiedli”9. Po wtóre zaś, ponieważ „są ludzie, którym się zdarza, że mylą się w rozumowaniach odnośnie [do] najprostszych nawet tematów geometrii i wyprowadzają z nich niewłaściwe wnioski, to sądząc, iż tak jak każdy inny byłem podatny omyłkom, odrzuciłem jako błędne wszystkie racje, które brałem poprzednio za dowody"10. Otóż, mając na uwadze tego

\footnotetext{
$7 \quad$ R. Descartes, Rozprawa o metodzie, dz. cyt., s. 33n.

8 Tamże, s. 38.

$9 \quad$ R. Descartes, Medytacje o pierwszej filozofii wraz z zarzutami uczonych mężów i odpowie-
} dziami autora, tłum. M. i K. Ajdukiewiczowie, S. Swieżawski, I. Dąmbska, t. 1, Warszawa 1958, s. 21.

10 Tenże, Rozprawa o metodzie, dz. cyt., s. 38. 
rodzaju pomyłki, zapytywał Kartezjusz w swych Medytacjach o pierwszej filozofii: „Skąd wiem, że tak jak o innych niekiedy sądzę, że się mylą w takich sprawach, o których - jak im się zdaje - posiadają doskonałą wiedzę, że tak samo ja sam nie ulegam złudzeniu, gdy dwa do trzech dodaję lub liczę boki kwadratu, albo gdy wykonuję coś jeszcze łatwiejszego, jeśli coś takiego da się pomyśleć?” ${ }^{11}$. A wreszcie, po trzecie, „Zważywszy, że wszelkie myśli, które mamy na jawie, mogą nas nachodzić również we śnie, z tym jednak, że wtedy żadna $\mathrm{z}$ nich nie jest prawdziwa, postanowiłem przyjąć, że wszystko, co kiedykolwiek znalazło się w moim umyśle, nie było bardziej prawdziwe, aniżeli moje senne widziadła"12. Albowiem - jak podkreślał - bardzo trudno jest wskazać takie niezawodne kryterium, które by nam pozwoliło odróżnić wszystko to, co przeżywamy na jawie, od tego, co staje się naszym udziałem podczas snu. Gdyż „często w nocy każe mi sen wierzyć w rzeczy zwyczajne np., że tu jestem, że jestem ubrany, że siedzę przy ogniu [...]. Gdy o tym myślę uważniej, widzę tak jasno, że nigdy nie można na podstawie pewnych oznak odróżnić jawy od snu, iż ogarnia mnie zdumienie i to zdumienie właśnie utwierdza mnie prawie w mniemaniu, że śnię" ${ }^{13}$ również obecnie, gdy właśnie piszę te słowa.

Jak niegdyś zwróciła na to uwagę Izydora Dąmbska, już Piotr Auriol, czternastowieczny francuski teolog i filozof, dawał wyraz przeświadczeniu, że „Bóg - jeśli zechce - może wywoływać w naszej świadomości treści zmysłowe, którym nie odpowiada żaden przedmiot transcendentny"14. Trudno powiedzieć, czy Kartezjusz znał ten pogląd Auriola. Niemniej jednak myśl ta, choć w trochę innej postaci, pojawiła się później w jego własnych rozważaniach. Idzie tu mianowicie o to, że Kartezjusz, ażeby nadać swojemu wątpieniu nieograniczony zasięg, przyjął w Medytacjach hipotezę, że istnieje jakiś przepotężny a złośliwy duch, który nieustannie nas zwodzi w odniesieniu do najrozmaitszych rzeczy i spraw.

11 Tenże, Medytacje o pierwszej filozofii, dz. cyt., s. 26.

12 Tenże, Rozprawa o metodzie, dz. cyt., s. 38.

13 Tenże, Medytacje o pierwszej filozofii, dz. cyt., s. 22n.

14 I. Dąmbska, Sceptycyzm francuski XVI i XVII wieku, dz. cyt., s. 19. 
Z tego też powodu - podkreślał - nawet nasze poczucie oczywistości twierdzeń matematycznych może być w nas złudnie wzbudzane przez owego złośliwego ducha. Mając to właśnie na uwadze, pisał: „Przyjmę więc, że [...] jakiś duch złośliwy a zarazem najpotężniejszy i przebiegły, wszystkie swe siły wytężył w tym kierunku, by mnie zwodzić. Będę uważał, że niebo, powietrze, ziemia, barwy, kształty, dźwięki i wszystkie inne rzeczy zewnętrzne są tylko zwodniczą grą snów, przy pomocy których zastawił on sidła na mą łatwowierność. Będę uważał, że ja sam nie mam ani rąk, ani oczu, ani ciała, ani krwi, ani żadnego zmysłu, lecz że mylnie sądziłem, iż to wszystko posiadam"15. Otóż - jak podkreślał następnie - jeśli będę trwać uparcie przy takim podejściu do wszystkiego, to „W ten sposób, choć może nie jest w mojej mocy poznać jakąkolwiek prawdę, to jednak będę się miał niezachwianie na baczności, żebym nie uznawał, o ile to możliwe, rzeczy fałszywych i żeby mi ten zwodziciel, chociażby nie wiem jak potężny i przebiegły, nie mógł niczego narzucić” ${ }^{16}$. Dlatego - kontynuował Kartezjusz - będę uparcie „odsuwał od siebie wszystko to, co najmniejszą choćby dopuszcza wątpliwość, zupełnie tak samo, jak gdybym był stwierdził, że jest to zgoła fałszem"17.

Zajmując tak radykalnie sceptyczną postawę względem wszystkiego, Kartezjusz nigdy przecież nie tracił z oczu podstawowego celu, do którego ostatecznie powinna go doprowadzić podjęta przezeń próba nieograniczonego wątpienia. Mając zawsze ten cel na uwadze, oraz będąc w pełni świadom niezwykłej wagi swego intelektualnego przedsięwzięcia, stwierdził: „Będę też podążał dalej, póki nie poznam czegoś pewnego, i jeśli już nie poznam niczego innego jako pewne, to przynajmniej to, że nie ma nic pewnego. Aby całą ziemię poruszyć z miejsca, żądał Archimedes tylko punktu, który by był stały i nieruchomy; należy więc oczekiwać wielkich rzeczy, jeżeli znajdę choćby coś najmniejszego, co byłoby pewne i niewzruszone"18.

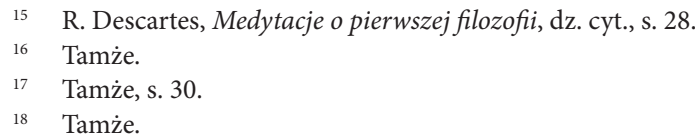




\section{Odkrycie przez Kartezjusza bezwzględnie pewnej zasady, dzięki której - jak sądził - będzie można zbudować nową filozofię}

Rzeczywiście też przeprowadzone przez niego metodyczne wątpienie we wszystko, pozwoliło mu niebawem odkryć coś takiego, co w żaden sposób nie podlega wątpieniu. Pewnego dnia uprzytomnił sobie mianowicie ten fakt, że przecież po odrzuceniu tego wszystkiego, co uznał za wątpliwe, pozostało jeszcze coś takiego, co musi zostać uznane za bezwzględnie pewne. W swej Rozprawie o metodzie tak o tym później wspominał: „zwróciłem uwagę na to, że w chwili, gdy chciałem tak myśleć, że wszystko jest fałszywe, stawało się konieczne, bym ja, którym tak myślał, był czymś. A spostrzegłszy, że ta prawda: myślę, więc jestem była tak niezachwiana i pewna, że wszelkie najbardziej dziwaczne przypuszczenia sceptyków nie zdołały jej zachwiać, uznałem bez obawy błędu, że mogę ją przyjąć jako pierwszą zasadę filozofii, której poszukiwałem" ${ }^{19}$. Zaś w Medytacjach o pierwszej filozofii wynik tych dociekań ujął on w ten sposób: „po wystarczającym i wyczerpującym rozważeniu wszystkiego, należy [...] stwierdzić, że to powiedzenie: «Ja jestem, ja istnieję» musi być prawdą, ilekroć je wypowiadam lub pojmuję umysłem" ${ }^{20}$.

Tak oto, na gruncie konsekwentnie przeprowadzonego metodycznego wątpienia we wszystko, Kartezjusz zdał sobie ostatecznie sprawę $\mathrm{z}$ tego, że owo metodyczne totalne wątpienie posiada jednak swoją nieprzekraczalną granicę. Albowiem owo totalne wątpienie kryje w sobie nieuchronnie bezwzględną pewność dotyczącą istnienia tego kogoś, kto tak radykalnie wątpi we wszystko. Jeśli bowiem rzeczywiście wątpię we wszystko, to przecież wówczas znaczy to nieuchronnie, że ja sam, który tak totalnie wątpię we wszystko, bezwzględnie muszę istnieć. Gdyż to moje totalne wątpienie we wszystko, stanowiąc pewną szczególną odmianę mojego myślenia, w żaden sposób nie daje się oddzielić ode mnie samego, który tak właśnie myślę. Wszak byłby czymś absurdalnym tego rodzaju stan rzeczy, że istniałoby samo tylko totalne

19 R. Descartes, Rozprawa o metodzie, dz. cyt., s. 38.

20 Tenże, Medytacje o pierwszej filozofii, dz. cyt., s. $31 \mathrm{n}$. 
wątpienie o wszystkim, bez tego kogoś, kto by to wątpienie spełniał. A zatem, skoro istnieje moje własne wątpienie, czyli szczególna odmiana mojego myślenia, to tym samym nieuchronnie muszę istnieć ja sam, który tak właśnie myślę. Tak oto ujawnia mi się w sposób nieodparty, że między jednym a drugim, czyli między moim własnym myśleniem a moim własnym istnieniem, zachodzi konieczny związek, którego nic nie jest w stanie podważyć. Wszystko to znaczy, że wyraźne uprzytomnienie sobie przeze mnie tego koniecznego związku „stawia opór powtarzającym się napadom zwątpienia i, co więcej, złośliwemu duchowi"21, choćby on - zgodnie z przyjętą przez Kartezjusza hipotezą - nieustannie nas zwodził, starając się we wszystkim wprowadzić nas w błąd.

Obecnie należy jeszcze zauważyć, że to myślenie, o jakim Kartezjusz cały czas mówił w swoich rozważaniach, rozumiał on w sposób bardzo szeroki. „Przez nazwę «myślenie» - wyjaśniał w Zasadach filozofii - rozumiem to wszystko, co w nas zachodzi, gdy jesteśmy świadomi, o ile jest w nas właśnie świadomość tych rzeczy. Tak więc nie tylko rozumienie, chcenie, wyobrażanie sobie, ale także i czucie [zmysłowe - R. R.] jest tutaj tym samym, co myślenie”22. Podkreślał zarazem, że ilekroć moje świadome czynności, takie na przykład, jak chodzenie, dotykanie i widzenie, ujmuję wyłącznie jako pewne odmiany mojego myślenia, tylekroć stwierdzam, że są mi one dane poznawczo w sposób tak samo nieodparty, jak moje własne istnienie. Natomiast, jeśli je traktuję jako czynności dokonywane realnie przez moje ciało, wtedy ich istnienie nie ujawnia mi się w tak nieodparty sposób. Kartezjusz tak o tym pisał: "gdy mówię: ja widzę, albo: ja chodzę, więc jestem, a mówiąc tak mam na myśli widzenie lub chodzenie wykonywane przez moje ciało, wniosek mój [że one realnie istnieją jako czynności mojego ciała - R. R.] nie jest bezwzględnie pewny, ponieważ - jak to często dzieje się we śnie - mogę sądzić, że widzę lub chodzę, choć nie otwieram oczu i nie ruszam się z miejsca; a mogłoby być tak samo bodaj, choćbym nie miał

21 G. Rodis-Lewis, Kartezjusz i racjonalizm, dz. cyt., s. 27.

22 R. Descartes, Zasady filozofii, tłum. I. Dąmbska, Kraków 1960, s. 10. 
wcale ciała”23. Dlatego całkowitą pewność odnośnie do tego, iż rzeczywiście chodzę po ziemi, widzę ją i dotykam jej, mogę mieć jedynie wówczas, gdy czynności te rozumiem wyłącznie jako rozmaite odmiany mojego myślenia. Gdyż wtedy moje przeświadczenie o tym, że np. widzę, bądź też, że chodzę, „dotyczy umysłu, który sam czuje, czyli myśli, że widzi, lub że chodzi" 24 .

Twierdzenie dotyczące koniecznego związku mojego (szeroko rozumianego) myślenia z moim własnym istnieniem ma charakter zasady, która - według Kartezjusza - jest czymś pierwszym w porządku myślenia, które poszukuje rzetelnie tego, co jest bezwzględnie pewne. Dlatego zasada ta stanowi jak gdyby fundament, na którym wreszcie (po raz pierwszy w dziejach) będzie można zbudować gmach filozofii, jako wiedzy pewnej. Wiedza tego rodzaju dotyczy tzw. idei jasnych i wyraźnych, ponieważ tylko one mogą być przedmiotami poznań bezwzględnie pewnych. Wiedzę tę określał Kartezjusz mianem „pierwszej filozofii”, co znalazło swój wyraz w tytule jego słynnych $\mathrm{Me}$ dytacji o pierwszej filozofii. Zgodnie też z jego przeświadczeniem owa „pierwsza filozofia”, czyli nowa metafizyka, stanowić będzie jak gdyby korzeń, z którego powinno następnie wyrastać wszelkie badawcze myślenie, jeżeli ma ono być w pełni rzetelnie uzasadnione. Znaczyło to dla niego, że $z$ tego jak gdyby korzenia stopniowo winny wyrastać nie tylko inne (pochodne względem metafizyki) działy filozofii, lecz w ogóle wszelkie dziedziny rzetelnej ludzkiej wiedzy. Kartezjusz tak to właśnie ujął w swym liście do Claude’a Picota, który przełożył z łaciny na język francuski jego Principia philosophiae. Stwierdził tam mianowicie: „cała filozofia przedstawia się jako drzewo, którego korzenie tworzy metafizyka [tj. jego „pierwsza filozofia” - R. R.] - pień fizyka, konarami zaś, które wyrastają z tego pnia, są wszystkie inne nauki, sprowadzające się do trzech podstawowych, mianowicie do medycyny, mechaniki i etyki"25. 


\section{Co wynika z zasady: myślę, więc jestem - dla rozjaśnienia istoty mnie samego?}

Zdaniem Kartezjusza ten konieczny związek, jaki zachodzi między moim myśleniem a moim istnieniem, konstytuuje mnie jako takiego. To zaś znaczy po prostu, że istnieję jako coś takiego, co ustawicznie myśli, i jak długo myśli, tak długo istnieje w sposób niewątpliwy. Ujął on to w ten sposób: „Tak: to myślenie! Ono jedno nie daje się ode mnie oddzielić. Ja jestem, ja istnieję; to jest pewne. Jak długo jednak? Oczywiście, jak długo myślę; bo może mogłoby się zdarzyć, że gdybym zaprzestał w ogóle myśleć, to natychmiast bym cały przestał istnieć" ${ }^{26}$. Otóż wypowiedź ta wyraźnie ukazuje, że Kartezjusz rozumiał ten konieczny związek mojego myślenia z moim własnym istnieniem jako bezpośredni oraz aktualny. Wszak, zgodnie $\mathrm{z}$ tą jego wypowiedzią, jestem bezwzględnie pewien mojego istnienia jedynie tak długo, jak długo aktualnie myślę, czyli jak długo spełniam jakąś (jakąkolwiek) odmianę mojego myślenia, taką na przykład, jak rozumowanie, sądzenie, wątpienie, wyobrażanie sobie, chcenie, odczuwanie, postrzeganie itp.

Znaczyło to dla niego, innymi słowy, że ilekroć przydarzałyby mi się takie sytuacje, kiedy nie mógłbym aktualnie myśleć - na przykład podczas omdlenia bądź w stanie narkozy - tylekroć wtedy istnienie moje stawałoby się niepewne, problematyczne. Albowiem bezwzględną pewność odnośnie do faktu mojego własnego istnienia posiadam jedynie wtedy, kiedy aktualnie myślę. Dlatego - jak podkreślał - ilekroć wyraźnie uprzytamniam sobie ten konieczny związek, jaki zachodzi między moim istnieniem a moim myśleniem, tylekroć wtedy „słusznie dochodzę do wniosku, iż moja istota polega na tym jedynie, że jestem rzeczą myślącą" ${ }^{27}$, czyli „substancją myślącą̨" ${ }^{28}$. Albowiem z całą pewnością istnieję jako „rzecz (substancja) myśląca” tylko wtedy, gdy aktualnie myślę, i tylko tak długo, jak długo aktualnie myślę. Ta zaś konstatacja, że na

\footnotetext{
26 R. Descartes, Medytacje o pierwszej filozofii, dz. cyt., s. 34.

27 Tamże, s. 103.

28 Por. tamże, s. 34.
} 
tym właśnie polega moja istota, stanowi nieuchronną konsekwencję tego podstawowego faktu, iż jestem czymś takim, co jest ukonstytuowane (tj. bytowo ukształtowane) przez ów konieczny związek mojego istnienia z moim aktualnym myśleniem.

Podsumowując w Medytacjach o pierwszej filozofii swoje rozważania, dotyczące kwestii jego własnego bytowego ukonstytuowania, Kartezjusz stwierdził: „Teraz przyjmuję tylko to, co jest koniecznie prawdziwe; jestem więc dokładnie mówiąc tylko rzeczą myślącą, to znaczy umysłem (mens) bądź duchem (animus), bądź intelektem (intellectus), bądź rozumem ( $r a-$ tio), wszystko [to są - R. R.] wyrazy o nie znanym mi dawniej znaczeniu. Jestem więc rzeczą prawdziwą i naprawdę istniejącą; lecz jaką rzeczą? Powiedziałem: myślącą”29. Albowiem - jak pisał na innym miejscu - „odrzucając to wszystko, o czym w jakiś sposób możemy wątpić, [...] nie przyjmiemy na tej podstawie tego, że my, którzy takie rzeczy myślimy, jesteśmy niczym; byłoby bowiem sprzecznością sądzić, że to, co myśli, w tym samym czasie, kiedy myśli, nie istnieje. I stąd - podkreślał - owo poznanie: ja myślę, więc jestem, jest tym, które ze wszystkich jako najpierwsze i najpewniejsze uderza każdego, kto filozofuje jak należy" ${ }^{\prime 30}$.

Otóż to, co Kartezjusz stwierdził na temat istoty samego siebie - ,jestem rzeczą, czyli substancją myślącą" - miało dla niego uniwersalną ważność: to znaczy dotyczyło istoty każdego człowieka. Tym samym przeciwstawił się on tradycyjnemu poglądowi, który głosił, że istotę bytu ludzkiego stanowi złożenie z rozumnej duszy oraz materialnego ciała. Albowiem przeprowadzone przez niego dociekania dotyczące ludzkiej natury (czyli tego, co konstytuuje istotę bytu ludzkiego), doprowadziły go do wniosku, że „do naszej natury nie przynależy żadna rozciągłość, ani kształt, ani ruch w jakimś miejscu, ani nic podobnego, co należy przypisać ciału, jedynie tylko samo myślenie; dlatego też poznaje się je wpierw i pewniej aniżeli jakiekolwiek rzeczy cielesne" ${ }^{\text {"31. }}$. Wszystko to zaś znaczy - podkreślał w Medytacjach - iż ,jest rzeczą pewną, że zaiste ja

\footnotetext{
29 Tamże.

30 R. Descartes, Zasady filozofii, dz. cyt., s. 9n.

31 Tamże, s. 10.
} 
jestem czymś różnym od mego ciała i bez niego mogę istnieć - ponieważ z jednej strony posiadam jasną i wyraźną ideę siebie samego jako rzeczy myślącej, a nie rozciągłej, a z drugiej strony wyraźną ideę ciała jako rzeczy rozciągłej tylko, a nie myślącej”32. Ta niezależność mojego istnienia jako „rzeczy myślącej” od istnienia mojego rozciągłego przestrzennie ciała, sugeruje najwyraźniej - zdaniem Kartezjusza - dalsze moje trwanie jako substancji myślącej po śmierci mojego ciała.

Zarazem jednak - podkreślał - jest dla mnie równie oczywiste to, że jestem taką rzeczą myślącą, która (w tym obecnym życiu) nigdy nie istnieje zupełnie sama, lecz zawsze jest w jakiś sposób złączona $\mathrm{z}$ ciałem, i dlatego ciało to uważam za „moje własne”. Znaczy to po prostu, że jestem przedziwnym złożeniem dwóch radykalnie odmiennych substancji. Otóż ta substancja, precyzował, „w której bezpośrednio tkwi myślenie, nazywa się umysłem; mówię tu raczej o umyśle niż o duszy, gdyż nazwa «dusza» jest wieloznaczna i często używa się jej dla oznaczenia rzeczy cielesnej3. [...] Substancja, będąca bezpośrednim podmiotem przestrzennej rozciągłości i przypadłości, które zakładają rozciągłość, jak kształt, położenie, ruch przestrzenny itd., nazywa się ciałem. [...] Powiada się [zaś - R. R.] o dwóch substancjach, że się rzeczywiście różnią, gdy każda z nich może bez drugiej istnieć" ${ }^{34}$.

A zatem, ponieważ - według Kartezjusza - w człowieku jego umysł i ciało są dwiema radykalnie odmiennymi substancjami, dlatego mogą one w nim spełniać właściwe sobie czynności całkiem niezależnie od siebie. Tak na przykład - wskazywał - „gdy rozważam ciało ludzkie jako pewien mechanizm tak urządzony i złożony z kości, nerwów, mięśni, żył, krwi i skóry, że gdyby nawet nie było w nim żadnego umysłu, to jednak [mechanizm ten - R. R.] miałby wszystkie te same ruchy, które teraz się w nim odbywają nie z nakazu woli”35. Jego zdaniem, tego rodzaju stan rzeczy ma właśnie miejsce w przypadku wszystkich zwierząt, jako tworów wyłącznie cielesnych.

\footnotetext{
32 R. Descartes, Medytacje o pierwszej filozofii, dz. cyt., s. 103.

33 Szło tu zapewne Kartezjuszowi o Arystotelesowskie wyrażenia „dusza wegetatywna” oraz „dusza zmysłowa”.

34 R. Descartes, Medytacje o pierwszej filozofii, dz. cyt., s. 199n.

35 Tamże, s. 111.
} 
Ustaliwszy w sposób bezwzględnie pewny to, czym on sam naprawdę jest, Kartezjusz odrzucił tym samym ostatecznie - jako pozbawione takiej pewności - wszystkie swoje poprzednie przeświadczenia, dotyczące tej sprawy. W swych Medytacjach tak o tym pisał na przykład: „Za cóż się tedy dotychczas uważałem? Oczywiście za człowieka, lecz czym jest człowiek? Mamże powiedzieć: istotą żyjącą rozumną? Nie! Gdyż następnie należałoby zapytać, czym jest istota żyjąca i czym rozumna, i w ten sposób zamiast jednego pytania stanęłoby przede mną kilka pytań jeszcze trudniejszych, nie mam zaś tyle wolnego czasu, abym go mógł poświęcić na takie subtelności” ${ }^{36}$.

\section{Czym jest spowodowane nasze poczucie oczywistej prawdziwości podstawowej zasady Kartezjusza?}

Podejmując rozważania dotyczące tej kwestii, postawmy najpierw następujące pytanie: cóż takiego sprawia, że ów szczególny związek, jaki zachodzi między naszym własnym myśleniem a naszym własnym istnieniem, uprzytamniamy sobie jako bezwzględnie konieczny? Otóż odnośnie do tej sprawy Kartezjusz stanowczo utrzymywał, że związek ten nie jest przez nas wywnioskowany, lecz że ujmujemy go bezpośrednio wglądem naszego umysłu. W swojej odpowiedzi na Zarzuty drugie tak o tym pisał: „gdy ktoś mówi: myślę, więc jestem, czyli istnieję, nie wyprowadza istnienia $\mathrm{z}$ myślenia drogą sylogizmu, lecz poznaje prostym oglądem umysłu jako rzecz oczywistą, jak się okazuje z tego, że gdyby tę [zasadę] wyprowadzał na drodze sylogizmu, powinien by był znać wprzód tę [przesłankę] większą: wszystko to, co myśli, jest, czyli istnieje; niewątpliwie jednak uczy się jej raczej na podstawie tego, co sam w sobie doświadcza, że [mianowicie] nie może być tak, by myślał, jeśliby nie istniał”"

Cóż jednak byłoby źródłem naszego poczucia bezwzględnej oczywistości, które dotyczy owego koniecznego związku, jaki ma miejsce między naszym własnym myśleniem a naszym własnym istnieniem? 
Otóż w tej sprawie mogłaby najpierw nasuwać się sugestia, że to nasze poczucie oczywistości ma swoje ukryte źródło w fakcie, iż zdanie: $m y$ ślę, więc jestem - stanowi pewnego rodzaju tautologię. Albowiem czyż nie jest tak, że już w samym tym krótkim stwierdzeniu: myślę - jest nieuchronnie zawarte, choć w sposób jedynie domyślny (tj. implicite), stwierdzenie dotyczące mojego własnego istnienia, że mianowicie istnieje jako myślący? Czyż treściowa zawartość stwierdzenia: myślę, nie jest równoważna treści stwierdzenia, że istnieje jako myślacy? Czyż nie jest niezbywalną cechą czasowników (nie tylko zresztą osobowych) to, że one, wyrażając w sposób jawny (explicite) określone czynności, stany itp., wyrażają tym samym, choć w sposób niejawny (implicite) istnienie podmiotu owych czynności bądź też stanów? Dlatego, zgodnie z powyższą sugestią, Kartezjuszową zasadę, która głosi: (skoro) myślę, więc jestem ( $t j$ istnieję), można by przekształcić w całkowicie równoważną jej znaczeniowo formułę: (skoro) jestem myślący, więc istnieję właśnie jako myślacy. Zarazem jest czymś oczywistym, że tego rodzaju przekształcenie nie wymaga żadnego sylogizmu, gdyż jest ono wynikiem prostego (tj. bezpośredniego) intelektualnego wglądu w zawartość znaczeniową słowa: myślę. Wszystko to rzeczywiście zdaje się wskazywać, że nasze poczucie koniecznej prawdziwości formuły: myślę, więc jestem - bierze się z faktu, iż mamy w niej do czynienia z ukrytą tautologią. Wiadomo zaś, że wszelkie tautologie cechuje nieodparta oczywistość, która narzuca się nam, ilekroć dokonujemy bezpośredniego wglądu intelektualnego w ich treść.

Czy jednak rzeczywiście powyższa sugestia jest słuszna? Czy owa podstawowa Kartezjuszowa zasada faktycznie stanowi swoistą tautologię? Ażeby uzasadnić wysuniętą właśnie wątpliwość, zauważmy, że stwierdzenie: (skoro) myślę, więc jestem, tylko wówczas byłoby tautologią, gdyby to moje własne istnienie, o którym jest tam domyślnie (implicite) mowa w wyrażeniu: myślę, miało dokładnie ten sam charakter, co to moje własne istnienie, które tam zostało explicite wyrażone w stwierdzeniu: więc jestem. Czy zatem rzeczywiście tak właśnie jest w obydwu członach tej zasady, tzn. w myśle oraz w więc jestem? Próbując obecnie rozstrzygnąć tę kwestię, zauważmy najpierw, że sam 
Kartezjusz wyraźnie stwierdził, że abym w ogóle mógł myśleć - czyli, abym kiedykolwiek mógł być myślącym - muszę już (uprzednio) istnieć. Ujął on to mianowicie w ten sposób: „w zdaniu myślę, więc jestem, nie ma nic innego, co by mnie upewniało, że mówię prawdę, jak tylko to, że widzę bardzo jasno, iż aby myśleć, trzeba istnieć” ${ }^{38}$. Stwierdzenie to wyraźnie ukazuje, że - jego zdaniem - to moje istnienie, o jakim jest explicite mowa w stwierdzeniu: więc jestem, ma najwyraźniej charakter czegoś logicznie uprzedniego w stosunku do tego mojego istnienia, o którym jest domyślnie (implicite) mowa w stwierdzeniu: myślę, czyli: jestem oto aktualnie myślacy.

Przytoczone właśnie powyżej Kartezjuszowe wyłuszczenie tego, na czym polega ten bezwzględnie konieczny związek, o którym mówi treść jego podstawowej zasady - a mianowicie, że „aby myśleć, trzeba istnieć” - wyraźnie pokazuje, iż moje własne już uprzednie istnienie warunkuje w ogóle możliwość tego, abym mógł kiedykolwiek aktualnie myśleć, czyli abym kiedykolwiek mógł istnieć jako aktualnie myślący. Znaczy to, innymi słowy, że w wyrażeniu: myślę, chodzi wyłącznie o ten mój własny sposób istnienia, który tu i teraz stał się oto moim udziałem, jako (moje własne) bycie aktualnie myślącym. Natomiast w stwierdzeniu: więc jestem, idzie o to moje własne istnienie, które warunkuje w ogóle możliwość każdego mojego aktualnego (tu i teraz) bycia oto myślącym. Wszystko to prowadzi do wniosku, że w obydwu członach Kartezjuszowej zasady, (czyli: w myślę oraz więc jestem) nie chodzi bynajmniej dokładnie o ten sam charakter (czy też sposób) mojego istnienia. Albowiem każde moje aktualne bycie myślącym może za każdym razem mieć miejsce jedynie dlatego, że już oto istnieję. Wszak, gdybym nie istniał, nie mógłbym tym samym w żaden sposób być kiedykolwiek aktualnie myślącym. Otóż wszystko to ostatecznie prowadzi do wniosku, że jednak Kartezjuszowa zasada: myślę, więc jestem - nie stanowi tautologii. A jest tak z tego powodu, ponieważ w wyrażeniach: myślę oraz więc jestem - chodzi o dwa, zasadniczo różne, sposoby istnienia tego bytu, do którego odnosi się owa zasada. 


\section{Jaką strukturę musi posiadać to istnienie, jakie stało się udziałem każdego $\mathrm{z}$ nas, ażebyśmy mogli kiedykolwiek aktualnie myśleć?}

Obecnie nasuwa się kolejne pytanie: na czym właściwie polega ów swoisty charakter (czy też sposób ukształtowania) tego naszego istnienia, na gruncie którego staje się dla każdego z nas w ogóle możliwe coś takiego, jak jego własne bycie oto aktualnie myślącym? Otóż, starając się rozjaśnić tę kwestię, należy najpierw podkreślić, że nie ulega żadnej wątpliwości, iż do tego, ażeby coś (cokolwiek) mogło aktualnie myśleć (czyli, ażeby mogło ono być czymś takim, co aktualnie myśli), nie wystarczy sam ten fakt, że to coś jakoś już po prostu istnieje. Albowiem na przykład ten fakt, że jakiś kamień już oto istnieje, w żaden sposób nie wystarczy do tego, ażeby ów kamień miał kiedykolwiek możność bycia czymś takim, co aktualnie myśli! A jest tak z tego powodu, że na gruncie tego sposobu istnienia, jaki stał się udziałem jakiegokolwiek kamienia, coś takiego jak myślenie, jest w ogóle niemożliwe. Wszak właściwy wszelkim kamieniom sposób istnienia jest na to zbyt prosty, ażeby mógł on warunkować ich możność bycia czymś takim, co jest zdolne do myślenia. Krótko mówiąc: wszelkie istnienie realizuje się zawsze jako „istnienie czegoś”, i z tego powodu realizuje się ono zawsze jako odpowiednie do natury tego czegoś, co je posiada. To zaś znaczy nieuchronnie, że „samo tylko istnienie”, czyli istnienie całkowicie w sobie niezróżnicowane, i wskutek tego niejako „oderwane” od natury czegoś (czegokolwiek) konkretnego, daje się nam pomyśleć tylko jako pewna intelektualna fikcja. A zatem, skoro istnienie realizuje się zawsze jako odpowiednie do natury tego czegoś, co je posiada, to tym samym - za każdym razem - charakteryzuje je odpowiednia struktura: taka, a nie inna.

Dlatego w zdaniu: myśle, więc jestem, słowo jestem nie może oznaczać jakiegoś całkowicie prostego istnienia, czyli istnienia całkowicie w sobie niezróżnicowanego, pozbawionego jakiejkolwiek struktury. Tak więc do tego, ażeby coś (cokolwiek konkretnego) mogło aktualnie myśleć, to istnienie, jakie stało się jego udziałem, koniecznie musi posiadać odpowiednią strukturę, gdyż dopiero dzięki temu staje się dla owego 
bytu możliwe coś takiego, jak myślenie. A zatem, ów konieczny związek czyjegoś aktualnego myślenia z jego własnym istnieniem (o którym mówi treść zasady Kartezjusza), nie dotyczy bynajmniej jakiegoś prostego (czyli całkowicie w sobie niezróżnicowanego, pozbawionego wszelkiej struktury) istnienia tego kogoś, kto aktualnie myśli, lecz odnosi się wyłącznie do takiego sposobu jego istnienia, które charakteryzuje się odpowiednią strukturą.

Otóż wszystko to wyraźnie wskazuje, że to moje człowiecze istnienie, o którym jest mowa w drugim członie Kartezjuszowej zasady, czyli w stwierdzeniu: „więc jestem” - nieuchronnie musi posiadać odpowiednią strukturę. Dokładniejsze zaś przemyślenie tej sprawy prowadzi do wniosku, że skoro aktualnie myślę, znaczy to nieuchronnie, że moim udziałem stało się takie istnienie, które posiada strukturę, w której należy wyróżnić te oto dwa podstawowe składniki:

(1) moje własne bycie czymś takim, co posiada zdolność myślenia;

(2) moje własne bycie czymś takim, co tę swoją zdolność myślenia potrafi $w$ odpowiednich warunkach aktualizować, to znaczy wtedy - przede wszystkim - gdy nie jestem (z jakiegoś powodu) nieprzytomny.

Wyróżnienie w strukturze mojego człowieczego istnienia tych dwóch podstawowych - splatających się ściśle ze sobą - sposobów jego realizowania się zdaje się wyraźnie ukazywać, że Kartezjuszowa interpretacja treści jego podstawowej zasady w sposób nazbyt ogólnikowy ujmowała charakter tego mojego człowieczego istnienia, które warunkuje w ogóle możliwość mojego bycia aktualnie myślacym. Idzie tu mianowicie o to, że w interpretacji podanej przez Kartezjusza został jakoś przeoczony ten podstawowy fakt, że to człowiecze istnienie, jakie stało się moim udziałem, posiada taką swoistą strukturę, która warunkuje w ogóle możliwość jakiegokolwiek mojego aktualnego myślenia (w tym szerokim znaczeniu myślenia, jakie on przyjmował). A tak jest zarówno w przypadku mnie samego, jak też kogokolwiek innego. Oczywiście, to czyjekolwiek bycie aktualnie myślacym może stać się jego udziałem jedynie w odpowiednich warunkach, to znaczy wtedy, gdy nie jest on nieprzytomny z jakiegoś powodu. 


\section{Zakończenie}

Całość rozważań przeprowadzonych w niniejszym artykule zdaje się ostatecznie prowadzić do wniosku, że podstawowa zasada Kartezjusza: myślę, więc jestem, posiada swoje ukryte założenia ontologiczne na temat swoistej struktury istnienia tego bytu, który (kiedykolwiek) aktualnie myśli. Założenia te odnoszą się - innymi słowy - do sposobu ukształtowania tego człowieczego bycia, jakie stało się moim udziałem (jak również każdego z nas). Albowiem - jak starały się to wykazać przeprowadzone poprzednio rozważania - zasada ta implikuje nieuchronnie, że udziałem każdego z nas stał się taki swoiście złożony sposób istnienia, dzięki któremu możemy w ogóle (kiedykolwiek) aktualnie myśleć. Analizy te ukazywały wszak dobitnie, że aby ktokolwiek z nas mógł kiedykolwiek aktualnie myśleć, nie może on po prostu „tylko jakoś istnieć”, czyli jego udziałem nie może być jakieś proste (całkowicie w sobie niezróżnicowane) istnienie. Gdyż do tego, ażeby ktokolwiek z nas mógł kiedykolwiek aktualnie myśleć ( $w$ tym szerokim, Kartezjuszowym rozumieniu myślenia), jego udziałem już uprzednio musiało się stać takie istnienie, które ma postać jak gdyby splotu dwóch swoistych sposobów bycia. $\mathrm{Na}$ splot ten składają się zaś nieuchronnie: (1) bycie już oto czymś takim, co posiada zdolność myślenia; oraz (2) bycie już oto czymś takim, co potrafi tę swoją zdolność aktualizować w odpowiednich warunkach (to znaczy wtedy, gdy nie jest się nieprzytomnym z jakiegoś powodu).

Rozważania te pozwalają tym samym stwierdzić, że - wbrew temu, co sugerował w tej sprawie Kartezjusz ${ }^{39}$ - każdy z nas z całą pewnością istnieje również wtedy, gdy z jakiegoś powodu (np. wskutek omdlenia bądź też narkozy) chwilowo wprawdzie aktualnie nie myśli, lecz przecież nadal istnieje jako potencjalnie zdolny do myślenia. To zaś, że każdy $\mathrm{z}$ nas nadal istnieje w ten sposób - na przykład w sytuacji omdlenia bądź narkozy - ujawnia się mu, gdy odzyska już świadomość, a wraz z nią możliwość aktualizowania (będącej nadal jego udziałem) zdolności do myślenia. Zaś wiarygodne świadectwo tych osób, które były świadkami 
jego minionego stanu omdlenia (bądź narkozy), dodatkowo upewnia go odnośnie do tego, że on rzeczywiście nadal istniał wtedy, kiedy aktualnie nie spełniał żadnej postaci swego myślenia.

Namysł nad tym koniecznym związkiem, jaki zachodzi między jego własnym myśleniem a jego własnym istnieniem, prowadził Kartezjusza do stwierdzenia na temat jego własnej istoty. Jak pamiętamy, ujął on to w słowach: „A jak jest z myśleniem? Teraz znalazłem! Tak: to myślenie! Ono jedno nie daje się ode mnie oddzielić. Ja jestem, ja istnieję; to jest pewne. Jak długo jednak? Oczywiście, jak długo myślę; [...] jestem więc dokładnie mówiąc tylko rzeczą myślącą, [...] Jestem więc rzeczą prawdziwą i naprawdę istniejącą; lecz jaką rzeczą? Powiedziałem: myślącą" A zatem, zgodnie z przeświadczeniem Kartezjusza, myślenie każdego $\mathrm{z}$ nas, jak długo jest przez nas aktualnie spełniane, tak długo konstytuuje naszą istotę, to znaczy nasze bycie czymś takim, co ciągle aktualnie myśli. Jednakże przeprowadzone przez nas analizy wyraźnie pokazują, że - wbrew temu, co sugerował Kartezjusz - nasze bycie aktualnie myślacymi bynajmniej nie konstytuuje istoty każdego z nas. Albowiem przeprowadzone przez nas rozważania prowadzą do wniosku, że do istoty człowieczego istnienia każdego $\mathrm{z}$ nas przynależą te dwa podstawowe sposoby jego realizowania się, o których była poprzednio mowa.

Mając to wszystko na uwadze oraz starając się dokładniej wyłuszczyć to, co jest implicite zawarte w treści Kartezjuszowej zasady, można by ją sformułować - na przykład - w taki sposób: skoro aktualnie myślę, znaczy to nieuchronnie, że jestem czymś takim, co posiadając zdolność myślenia, może zarazem urzeczywistniać tę swoja zdolność w odpowiednich warunkach. Sformułowanie to dokładniej pokazuje, na czym właściwie polega ten bezwzględnie konieczny związek, jaki zachodzi między własnym myśleniem a własnym człowieczym istnieniem każdego z nas. 